\title{
Systemic and venous thromboembolism in metabolic syndrome: Two faces of the same disease
}

\author{
Tamara Kovačević-Preradović ${ }^{1,2}$, Bojan Stanetić1,2, Ljiljana $\operatorname{Kos}^{1,2}$, Vlastimir Vlatković2,3 \\ ${ }^{1}$ Department of Cardiology, University Clinical Centre of the Republic of Srpska, Banja Luka, Bosnia and \\ Herzegovina, ${ }^{2}$ Medical School, University of Banja Luka, Banja Luka, Bosnia and Herzegovina, ${ }^{3}$ Department of \\ Nephrology, University Clinical Centre of the Republic of Srpska, Banja Luka, Bosnia and Herzegovina;
}

Abstract

Genetic factors have been shown to raise the risk of thromboembolic events such as pulmonary embolism as well as stroke. Here we present a case of acute systemic and venous thromboembolism.

Key words

venous and arterial thrombosis, metabolic syndrom, paroxysmal atrial fibrillation, anticoagulation

\section{Case presentation}

W e present a case of a 54-year-old woman admitted to the hospital due to dyspnoea and pain in the left arm. Her medical history revealed the diagnosis of metabolic syndrom, three years preceeding the current condition, with the BMI (body mass index) of $35 \mathrm{~kg} / \mathrm{m} 2$, HDL level is below $1.0 \mathrm{mmol} / \mathrm{l}$, Trygliceride level of $2.3 \mathrm{mmol} / \mathrm{l}$, fasting blood glucosae level of $6.7 \mathrm{mmol} / \mathrm{l}$ and $\mathrm{HbA} 1 \mathrm{c} 6.0 \%$. Patient reported several episodes of short-lasting paroxysmal atrial fibrillation (AF) in the last two years. Ten days before admission, she underwent surgery consisted of great saphenous vein ligation with additional phlebectomy of the varicose veins. No anticoagulation was recommended postoperatively. Physical findings on admission were tachycardia, tachypnea, accentuated second heart sound on heart auscultation and cold, pale, painful, pulseless left upper extremity. ECG showed sinus tachycardia and nonspecific ST-T wave abnormalities. Bedside transthoracic echocardiography found right ventricular enlargement and hypokinesis of the free wall with estimated right ventricular systolic pressure of $80 \mathrm{mmHg}$. CT pulmonary angiography confirmed the presence of the emboli in both the left and right main pulmonary arteries (Figure 1). Additionally $\mathrm{CT}$ angiography of the left arm was performed and revealed occlusion of the proximal left subclavian artery (Figure 2 and 3). The immediate surgical thrombectomy was succesfully performed. Unfractionated heparin, administered by continuous infusion adjusted to achieve activated partial thromboplastin time (APTT) greater than 1.5 was administred. Oral anticoagulation with rivaroxaban was started on the fifth day. The evaluation of the discovered plasminogen-activator inhibitor-1 (PAI-1) gene polymorphism as well the MTHFR gene mutation.

\section{Discussion}

The pathogenesis of venous and arterial thrombosis may be different, however, both thrombosis may occur in any given patient with a thrombophilic state. Thrombophilic state is defined trough hypercoagulable state, that refers only to changes in blood coagulation, and trough changes in vessel walls or blood flow as well. Vessel wall changes play an important role in both arterial and venous thrombosis.

Arterial thrombosis occurs mainly due to the erosion or rupture of an atherosclerotic plaque and arterial thrombi are mainly constituted by platelets. Venous changes, such as those created by valve destruction and varicosities, often play a role in the pathogenesis of thrombosis. But combination of stasis and hypercoagulability, much more then endothelial damage itself, is crutial for the development od venous thrombosis. In comparison to arterial thrombi, venous thrombi are mainly constituted by fibrin and red blood cells and less by platelets.

Thrombophilia has both acquired and inherited causes. Tests for heritable thrombophilia should be considered for patients with higher risk of venous and arterial thromboembolic events. Inherited thrombophilia refers to inherited deficiencies of natural inhibitors and inherited mutations of coagulation factors. Inherited protein $\mathrm{C}$ and $\mathrm{S}$ and antithrombin deficiencies are strong risk factors for venous thrombosis with little effect on arterial thrombosis. The most common inherited risk factor for venous thrombosis is mutation for factor $V$ gene (factor $V$ Leiden) and mutation in the prothrombin gene. The prevalence of these mutations in general population is in the range $3-6 \%$, and in patients with venous thrombosis reaches $21 \%^{1}$. Antiphospholipid antibody syndrome is one of the most important acquired risk factors for both, arterial and venous thrombosis. Lupus anticoagulant, an- 


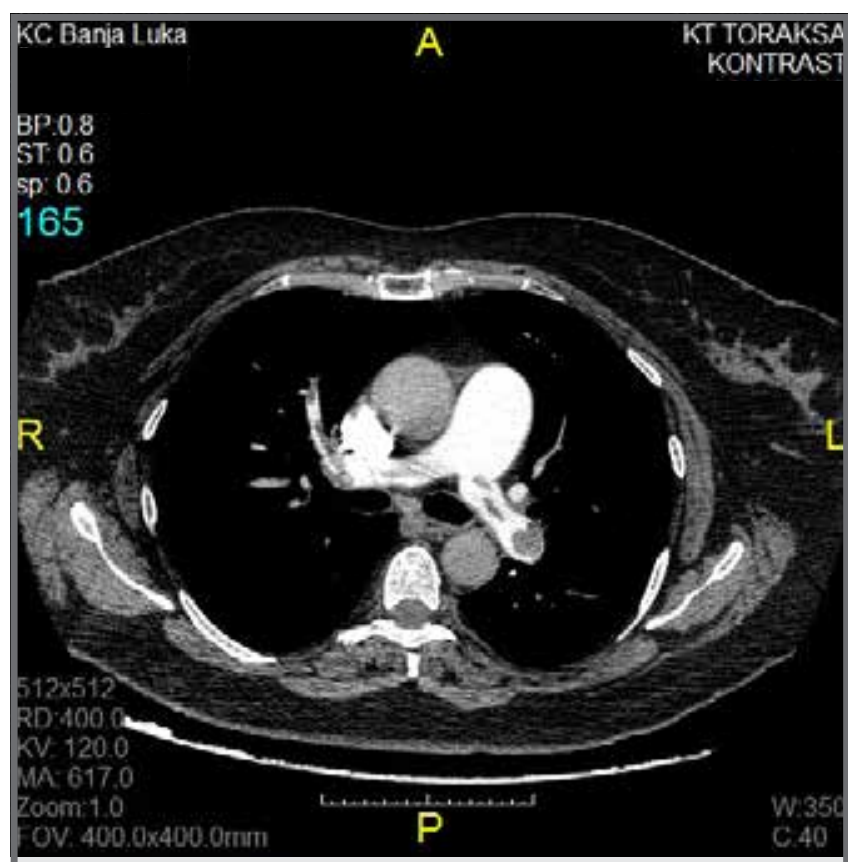

Figure 1. CT pulmonary angiography showing the presence of the emboli in both the left and right main pulmonary arteries

ticardiolipin and anti- $\beta 2$-glycoprotein I antibodies are clinically relevant antiphospholipid antibodies. Mixed coagulation risk factors are hyperhomocysteinaemia and increased plasma levels of coagulation factors (fibrinogen, factor VIII, factor IX and factor XI).

The metabolic syndrome is also considered to be the risk factor for both, arterial and venous thrombosis ${ }^{2,3}$. According to the definition proposed in 2001 by the $\mathrm{Na}$ tional Cholesterol Education Program Adult Treatment Panel III (NCEP ATP III), a person is considered to have the metabolic syndrome if he or she has at least three of the following risk factors: overweight or obesity, glucose intolerance, hypertension, high level of triglycerides and/ or low level of high-density lipoprotein (HDL) cholester$\mathrm{Ol}^{4}$. On the other hand, the American Diabetes Association (ADA) promotes using the term "cardiometabolic risk" since there are other factors which greatly increase the risk for cardiovascular disease, both nonmodifable (age,sex, family hystory) and modifable (hypercoagulation, smoking, inflammation, absence of physical activity). The metabolic syndrom itself is often accompanied by a prothrombotic state including increased plasma levels of factor VII, VIII, fibrinogen, and with increased levels of PAI-1, the latter leading to a hypofibrinolytic state ${ }^{5,6}$. The increased level of fibrinogen is associated with chronic inflammation and insulin resistance, both present in metabolic syndrom. On the other hand, insulin resistance and chronic inflammation contribute to the increase in PAI-1, the major inhibitor of fibrinolysis, as well.

The fibrinolytic system and its relation to AF with associated underlying mechanisms are not completely understood. Previous studies have shown the role of inflammation, endothelial damage, and fibrinolysis with the confounders such as hypertension or insulin resistance in the development of $\mathrm{AF}^{7}$. The PAI-1 level was considered as an independent predictor for $\mathrm{AF}$ after

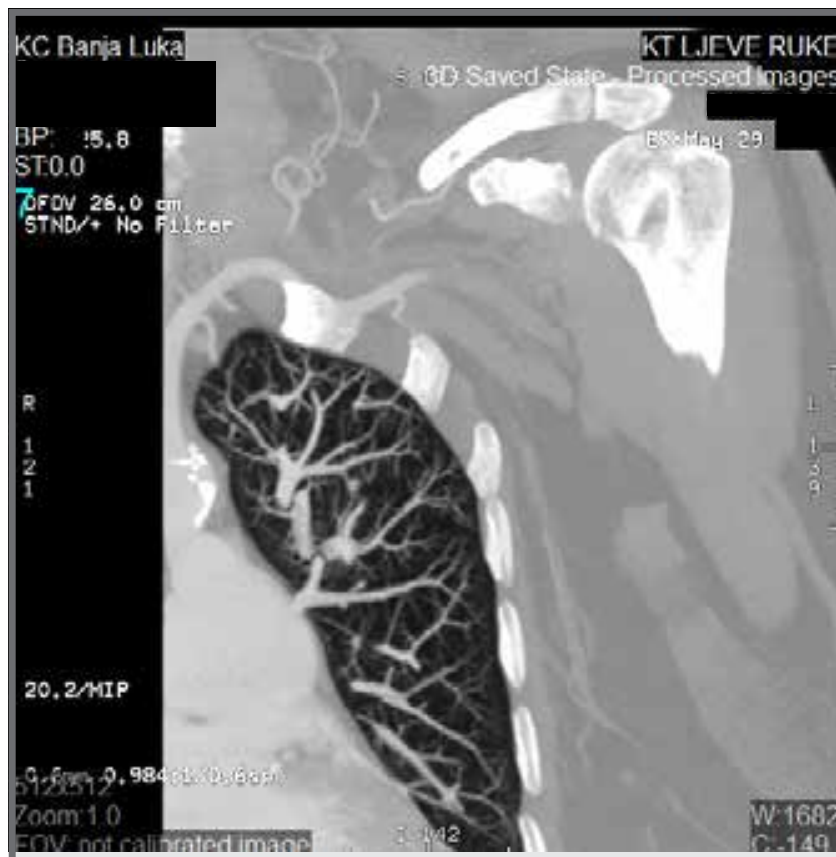

Figure 2. CT angiography of the left arm showing occlusion of the proximal left subclavian artery

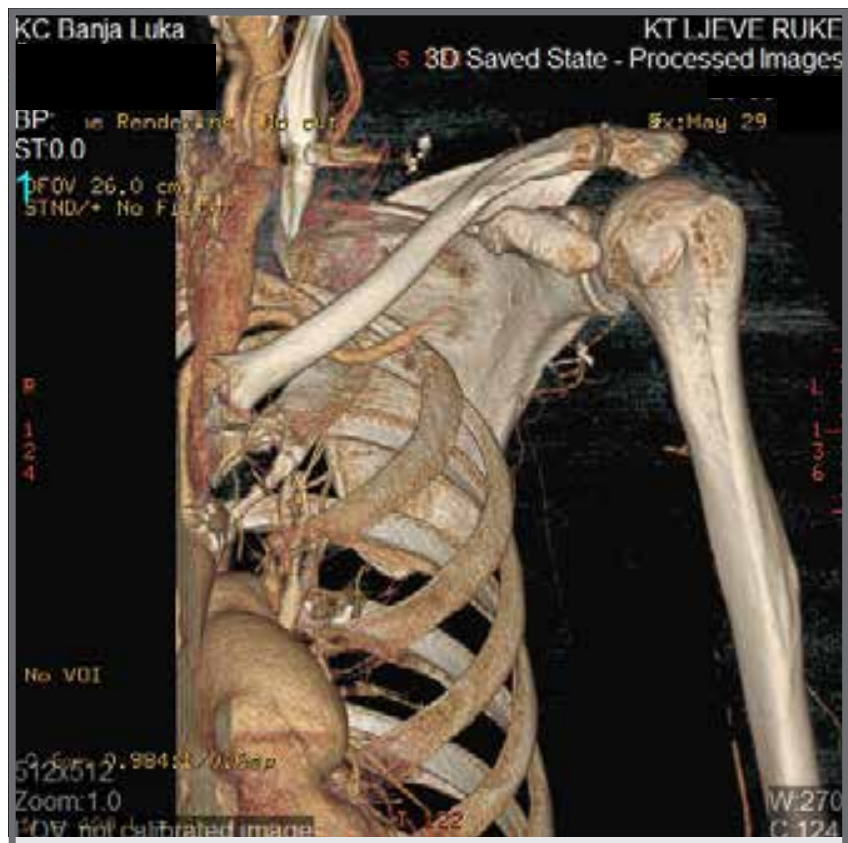

Figure 3. CT angiography of the left arm with 3D reconstruction

coronary artery bypass surgery ${ }^{8}$ and the data suggest the PAI-1 levels to be predictive of a successful cardioversion ${ }^{9}$. But recent data from PREVEND study failed to determine the association of PAI-1 and TPA (Tissue-type plasminogen activator) levels with incident $A F^{10}$.

\section{Conclusion}

In the patient with the combination of two weak thrombophilias, heterozygotes for plasminogen-activator inhibitor-1 (PAI-1) gene polymorphism as well the MTHFR gene mutation, in the context of metabolic syndrome and classical risk factors could reveal life threatening thromboembolism. 


\section{References}

1. Stevens SM, Woller SC, Bauer KA, Kasthuri R, Cushman M, Streiff $M$, et al. Guidance for the evaluation and treatment of hereditary and acquired thrombophilia. J Thromb Thrombolysis 2016;41(1):154-64.

2. Dentali F, Romualdi E, Ageno W. The metabolic syndrome and the risk of thrombosis. Haematologica 2007;92(3):297-9.

3. Ageno W, Prandoni P, Romualdi E, Ghirarduzzi A, Dentali F, Pesavento $R$, et al. The metabolic syndrome and the risk of venous thrombosis: a case-control study. J Thromb Haemost 2006; 4(9):1914-8.

4. Grundy SM, Cleeman JI, Daniels SR, Donato KA, Eckel RH, Franklin BA, et al. Diagnosis and management of the metabolic syndrome: an American Heart Association/National Heart, Lung, and Blood Institute scientific statement: Executive Summary. Crit Pathw Cardiol 2005;4(4):198-203.
5. Raynaud E, Perez-Martin A, Brun J, Aissa-Benhaddad A, Fedou $C$, Mercier J. Relationships between fibrinogen and insulin resistance. Atherosclerosis 2000;150(2):365-70.

6. Vaughan DE. PAI-1 and atherothrombosis. J Thromb Haemost 2005;3(8):1879-83.

7. Marin F, Roldan V, Lip GY. Fibrinolytic function and atrial fibrillation. Thromb Res 2003;109(5-6):233-40.

8. Pretorius M, Donahue BS, Yu C, Greelish JP, Roden DM, Brown NJ. Plasminogen activator inhibitor-1 as a predictor of postoperative atrial fibrillation after cardiopulmonary bypass. Circulation 2007;116(11 Suppl):I1-7.

9. Tveit A, Seljeflot I, Grundvold I, Abdelnoor M, Smith P, Arnesen $\mathrm{H}$. Levels of PAI- 1 and outcome after electrical cardioversion for atrial fibrillation. Thromb Res 2008;121(4):447-53.

10. Mulder BA, Geelhoed B, van der Harst P, Spronk HM, Van Gelder IC, Asselbergs FW, et al. Plasminogen activator inhibitor-1 and tissue plasminogen activator and incident AF: Data from the PREVEND study. Int J Cardiol 2018.

\title{
Sažetak i prikaz slučaja
}

\section{Sistemski i venski tromboembolizam u metaboličkom sindromu: dva lica iste bolesti}

\author{
Tamara Kovačević Preradović1 ${ }^{1}$ Bojan Stanetić1,2, Ljiljana Kos ${ }^{1,2}$, Vlastimir Vlatković ${ }^{2,3}$
}

${ }^{1}$ Klinika za kardiologiju, Klinički Centar Republike Srpske, Banja Luka, Bosna i Hercegovina, ${ }^{2}$ Medicinski fakultet, Univerzitet u Banja Luci, Banja Luka, Bosna i Hercegovina, ${ }^{3}$ Department of Nephrology, Univerzitetski Klinički Centar Republike Srpske, Banja Luka, Bosna i Hercegovina

Dokazano je da određeni genetski faktori povećavaju rizik od nastanka tromboembolijskih događaja kao što su plućna embolija i ishemijski moždani udar. Ovde predstavljamo slučaj sa akutno nastalim istovremenim sistemskim i venskim tromboembolizmom. Pacijentkinja starosti 54 godine je primljena u bolnicu zbog naglo nastale dispneje i bola u lijevoj ruci. Tri godine prije aktuelnog događaja, postavljena je dijagnoza metaboličkog sindroma na osnovu BMI (indeksa tjelesne mase) od $35 \mathrm{~kg} / \mathrm{m}^{2}$, vrijednosti HDL holesterola manje od $1.0 \mathrm{mmol} / \mathrm{l}$, triglicerida $2.3 \mathrm{mmol} / \mathrm{l}$, glikemija našte $6.7 \mathrm{mmol} / \mathrm{l}$ i HbA1c 6.0\%. Pacijentkinja navodi i nekoliko epizoda kratkotrajne fibrijacije atrija (AF) tokom prethodne dvije godine. Deset dana prije ove hospitalizacije, pacijentkinja je imala operaciju podvezivanja velike potkožne vene (lat. vena saphena magna) sa dodatnom flebektomijom varikoziteta. Postoperativno nije preporučena antikoagulantna terapija. Fizikalnim nalazom na prijemu nađe se tahikardija i tahipneja; auskultatorno naglašen drugi srčani ton te hladna, blijeda i bolna lijeva ruka bez perifernih pulzacija. Na EKG zapisu sinusna tahikardija uz nespecifične promjene ST spojnice i T talasa. Transtoraksna ehokardiografija izvedena kraj bolesničkog kreveta pokaže uvećanje desne komore sa hipokinezijom slobodnog zida i procijenjenim sistolnim pritiskom u desnoj komori od $80 \mathrm{mmHg}$. CT pulmonalna angiografija potvrdi prisustvo tromba u obje glavne grane plućne arterije (Slika 1). Odmah se učini i dodatna CT angiografija lijeve ruke koja pokaže okluziju lijeve potključne arterije u proksimalnom dijelu (Slika 2,3). Hitna hirurška trombektomija je uspješno izvedena. Nakon toga je ordinirana kontinuirana infuzija nefrakcionisanim heparinom, uz kontrolu aktiviranog parcijalnog tromboplastinskog vremena (APTT) sa ciljnom vrijednosti produženja vremena preko 1.5 puta. Peti dan infuzije započne se oralna antikoagulantna terapija rivaroxabanom. Dijagnoastičkom evaluacijom trombofilije, ustanovIjen polimorfizam gena inhibitora aktivatora plazminiogena 1 (PAl-1) kao i mutacija MTHFR gena.

Ključne reči: arterijska i venska tromboza, metabolički sindrom, paroksizmalna atrijalna fibrilacija, antikoagulacija 